\title{
Hungarikumok területi jelentőségének vizsgálata, különös tekintettel a pálinkára
}

\section{Examination of the territorial significance of Pálinka as a Hungaricum}

\author{
KÁPOSZTA JÓZSEF, RITTER KRISZTIÁN, KASSAI ZSUZSANNA
}

\begin{abstract}
KÁPOSZTA József: dékán, intézetigazgató, egyetemi docens, Szent István Egyetem, Gazdaság- és Társadalomtudományi Kar, Gödöllő; Dekan@gtk.szie.hu

RITTER Krisztián: intézetigazgató-helyettes, egyetemi docens, Szent István Egyetem, Gazdaság- és Társadalomtudományi Kar, Gödöllő; Ritter.Krisztian@gtk.szie.hu

KASSAI Zsuzsanna: egyetemi adjunktus, Szent István Egyetem, Gazdaság- és Társadalomtudományi Kar, Gödöllő; Kassai.Zsuzsanna@gtk.szie.hu
\end{abstract}

KULCSSZAVAK: pálinka, hungarikum, endogén fejlesztés

ABSZTRAKT: Az endogén forrásokra épülő gazdaságfejlesztés számos hazai kistérségben kitörési pontot jelenthet a hosszú távú fejlesztések terén. Ennek vizsgálatát a Magyar Értéktárban nyilvántartott négy eredetvédett pálinka - a békési szilva-, a gönci barack-, a kecskeméti barack- és a pannonhalmi törkölypálinka - területi hatásaira fókuszálva végeztük el. Szekunder adatgyűjtést követően 2014 tavaszán mélyinterjúkat készítettünk az érintett hungarikumok előállításában, gondozásában részt vevő személyekkel, turisztikai szolgáltatókkal és a helyi vidékfejlesztés fontosabb szereplőivel. A kutatási eredményeink igazolták, hogy a hungarikumok eloállítása számos közvetlen és főleg közvetett haszonnal jár a vizsgált térségek társadalmára és gazdaságára, igaz, egyelőre még korlátozott mértékben. Hozzájárulnak többek között a helyben történő munkahelyteremtéshez és -megőrzéshez, a helyi vendéglátás és turizmus serkentéséhez, az alapanyag-előállítók és a szeszfőzdék bevételeinek, így a helyi adóbevételeknek a növekedéséhez. Emellett a kiváló minőségű termékek diverzifikációs lehetőséget nyújtanak a helyi gazdálkodók számára, továbbá a hungarikum védjegy hozzájárul a vizsgált térségek ismertségének növeléséhez is. Primer kutatásunk alapján a kérdéses pálinkák kiérdemelték a hungarikum védjegyet, hiszen sajátos endogén erőforrásokat jelentenek, amelyek bár korlátozottan, de minőségük révén az országimázs alakításához is hozzájárulnak. A kutatás arra is rávilágított, hogy nagyobb figyelmet kellene fordítani országosan is az endogén forrásokra alapozott kézműves termékek értékteremtésére, helyi gazdaságfejlesztési lehetőségeikre. Ehhez viszont további állami beavatkozásokra, például a törvényi szabályozás módosítására, célzott támogatásokra volna szükség. Fontos megállapításunk az is, hogy az általunk tanulmányozott hungarikumok egyáltalán nem vagy nem elég hangsúlyosan jelennek meg az érintett térségek fejlesztési stratégiáiban, terveiben. Ezért a 2014 és 2020 közötti időszakban véleményünk szerint nagyobb figyelmet kell fordítani ezen endogén erőforrások nemzeti és helyi fejlesztési stratégiákba való beépítésére.

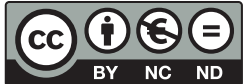


József KÁPOSZTA: dean, head of institute, associate professor, Faculty of Economics and Social Sciences, Szent István University, Gödöllő; Dekan@gtk.szie.hu

Krisztián RITTER: deputy head of institute, associate professor, Faculty of Economics and Social Sciences, Szent István University, Gödöllo”; Ritter.Krisztian@gtk.szie.hu

Zsuzsanna KASSAI: assistant professor, Faculty of Economic and Social Sciences, Szent István University, Gödöllo’; Kassai.Zsuzsanna@gtk.szie.hu

KEYWORDS: indigenous development, hungaricum, palinka

ABSTRACT: In numerous regions, economic development based on indigenous resources can be a take-off point of long-term development. This paper focuses on the territorial impact of four Pálinka fruit brandys under protection of designation of origin as registered in the Hungarian Repository of Values. They are the Pálinka made of plum of Békés, apricot of Göncz and Kecskemét and a grape-based pomace brandy of Pannonhalma.

After an extended literature review and secondary data collection (which includes an analysis of local rural and regional development strategies, plans and territorial database of the Hungarian Central Statistical office) 63 in-depth interviews were conducted in the spring of 2014. The interviewees were people who took part in the production and management of the Hungaricums examined, tourism providers and the most important actors of local rural development. The research findings proved that the production of these Hungaricums provided several direct and indirect benefits for the economy and society of the regions examined. Among others factors, Pálinka contributed to local job generation and preservation, growth of income of producers of raw materials and distilleries and thus to the increase of local tax revenues and stimulation of local catering and tourism.

The significance of Hungaricums increased in regional programmes and touristic programmes in the research area. However, cooperation among the actors of tourism, Pálinka producers and local government was not typical. Although some good examples were revealed, in our opinion the willingness to co-operate among local actors could still be improved. It also emerged that premium-quality products provided diversification opportunities for local farmers and helped the integration of socially disadvantaged groups.

The Hungaricum certification made a significant contribution to the increased reputation of the regions studied and promoted the country's image to a limited extent, too. It was also found that the four Pálinka brandys surveyed have rightly deserved Hungaricum certification, since they are such specific indigenous products, which are outstanding not only on the national level, they compare well on the international level, too. Our investigations highlight that these indigenous products should be even better exploited in the future. To achieve this aim, further state interventions (e.g. change of legislative regulations, etc.) and specific subsidies would be necessary. The Hungaricums investigated have not been presented meaningfully or even not at all in strategical and regional planning documents. Therefore, in our opinion, more attention should be paid to integrating these indigenous resources - being in accordance with interventions concerning the collection, research, popularisation and management of national values - into the national and local development period of 2014 and 2020.

\section{Bevezetés}

A világgazdaságban lejátszódó folyamatok, a globalizáció egyik következménye a térségek, a lokalitások szerepének megváltozása és felértékelődése, ami azt is eredményezte, hogy a versenyképesség feltételeinek kialakítása mára nem csupán a kormányok felelősségkörébe tartozik, hanem az endogén fejlődéselméle- 
tek előtérbe kerülésével az egyes települések, térségek feladatává is vált. Az új területi politikák következtében hazánkban is fontos szerepet kapnak a lokális, endogén erőforrások mint az önerőből történő építkezés alapkövei, amelyek megfelelő körülmények közt aktivizálhatók (Káposzta 2007). Az endogén elméletek szerint a fejlesztések akkor lehetnek eredményesek, ha - miközben a regionális és globális hálózatokhoz való kapcsolódást teszik lehetővé (Lowe, Murdoch, Ward 1995) - teret adnak a helyi részvételnek és a helyi kezdeményezéseknek (Cernea 1992), egyértelműen az adott terület helyi (természeti, gazdasági, humán, kulturális) erőforrásaira alapoznak (Kulcsár 2006; Ploeg, Dijk 1995). Eközben az önerős fejlesztés révén hosszú távon elszakadnak a külső támogatás okozta függőségtől, és a fenntartható fejlődést szolgálják (Murdoch 1995). Terluin és Post (2001), valamint Farkas (2002) alapján a helyi erőforrások mellett a helyi tevékenységek és a helyi szereplők fontossága, valamint az integrált megközelítés is meghatározó. Ebben - Kis és Szekeresné (2010) szerint - a helyi szervezetek (például a helyi akciócsoportok) összefogó tevékenységének kiemelkedő szerepe van. Moseley (2003) szerint a helyi erőforrások előnyben részesítése az importált nyersanyag és tőke preferálása helyett biztonságosabb és fenntartható jövőt teremt a gazdasági fejlesztés számára. Ehhez a helyi erőforrások és az új üzleti lehetőségek ismerete, valamint megfelelő hozzáértés szükséges. A helyi erőforrások igénybevétele biztosítja, hogy a befektetett tőke helyben marad és újrahasznosul. Emellett a helyi sokszínűség hangsúlyozása és reklámozása, a hely jellegzetességeinek támogatása, a helyi identitás, valamint a hozzákapcsolódó különféle minőségi áruk és szolgáltatások fejlesztése és értékesítése a globalizációval szembeni védelmet is jelenti.

Természetesen a helyi erőforrásokra épülő gazdaságfejlesztés akkor tud meghatározó szerephez jutni egy adott térség gazdasági növekedésében, ha az eloállított termék értékesítése révén jövedelmet teremt a további fejlesztésekhez. Belletti, Marescotti és Scaramuzzi (2003) alapján a helyi termékek kapcsolódását egy adott térség vidékfejlesztéséhez az biztosítja, ha ezen termékeket az előállítási helyszínükkel való szoros kötődés teszi egyedivé, ami a keresletüket is nagymértékben befolyásolja. Így az érintett vidéki területeknek potenciális és unikális erőforrásként kell tekinteniük ezekre a termékekre. Endrighi (1999) szerint a helyi, egyedi termékek alapvetően kétféle módon befolyásolhatják eloállítási helyük környezetét:

- a termék sikere gazdasági hasznot hoz az azt eloállító vállalkozások számára, illetve a termék ismertségének növekedése kihat a helyi gazdaság többi szereplőire (például az idegenforgalomra, vendéglátásra, kézművességre);

- a termék sikere többnyire csak a helyi lakosság bevonásával érhető el (például munkaerőként alkalmazva), amely magával hozza a társadalmi kohézió és az identitástudat erősödését is.

Pacciani és társai (2001) arra hívják fel a figyelmet, hogy a helyi különleges termékek értéknövelésében érdekelt szereplők nagymértékben különbözhetnek egymástól, és mindegyik fél a saját érdekét tartja szem előtt. Egyes szerep- 
lők közvetlenül is részt vesznek a termék előállításában, míg mások csak közvetett szerepet töltenek be, esetenként nem is az eloállítás helyszínén tevékenykednek. A szereplők érdekeltségeit alapvetően az határozhatja meg, hogy az érintettnek mi a célja, illetve hogy a régiónak mint a termék eloállítási helyszínének milyen szerep jut. Az érintettek célja alapján megkülönböztethetünk olyan stratégiát, amely csak magának a terméknek az előállítási és értékesítési folyamatára (a termelési és ellátási láncra) koncentrál, illetve azt a stratégiát, amikor a helyi gazdaság és társadalom egésze a célcsoport (kiterjesztett nézőpont). Az elóállítási helyszín - a stratégiában betöltött szerepe alapján - lehet csak egy minőségi ismertetőjel, de akár az adottságok kifejezője is. Minőségi ismertetőjelként (garanciaként) a származási hely pontos megjelölése arra szolgál, hogy segítsen a vásárló számára megkülönböztetni az adott terméket a többi hasonló terméktől. Adottságok kifejezőjeként az eloállítási hely egy gyüjtőfogalom, amely a régióhoz kötődő termék- és szolgáltatáskosár együttesét fejezi ki. A termék szoros értelemben vett ellátási lánca mellett figyelmet szán a kapcsolódó ágazatoknak is, és általánosságban véve szolgálja az adott térség érdekeit (Török 2012). Mindezek alapján (figyelembe véve a hazai unikális javak szűkösségét), ebben a sokváltozós viszonyrendszerben az újabb és újabb fejlesztési stratégiák kidolgozását elsősorban a régiókon belüli lehetőségekre, az endogén potenciálok kiaknázására, a saját erők megújítására és fejlesztésére kell alapozni az adott térségekben. De felmerül a kérdés: mi várható az endogén forrásokra épülő fejlesztésektől? A nemzetközi és hazai tapasztalatok alapján megállapítható, hogy az endogén forrásokra épülő fejlesztések hatására új impulzusok érhetik a célterületet, új fejlesztési, foglalkoztatási irányok alakulhatnak ki. Fontosnak tartjuk annak vizsgálatát, hogy miként lehet a területi tényezőket hatékony allokációval beilleszteni az adott társadalmi termelés és tevékenységek rendszerébe, úgy, hogy azok működése optimális legyen. E fejlesztés elmélete a generatív növekedési koncepcióból ered, amely a lokális fejlődési teljesítményekből vezeti le a helyi, területi gazdasági növekedést, így a lokális komparatív előnyökre épülő gazdaságfejlődés összessége szolgál alapul a regionális fejlesztésekhez. A lokális potenciálok mint endogén erőforrások roppant széles skálán mozognak. Kiinduló feltételezés, hogy az „egyes településekben, térségekben található földrajzi, környezeti, történelmi, kulturális, társadalmi, gazdasági tényezők együttes rendszerének értelmezése és az ezen értéktartományok aktivizációját befolyásoló tényezők" (Rechnitzer, 1990, 49.) meghatározó szerepet tölthetnek be a hely, a térség modernizációs pályára állításában.

Vidékfejlesztési szempontból bár mindkét stratégia pozitív hatásokat hoz létre, a termék adottságaira koncentráló stratégiától való elmozdulás a térség adottságaira figyelő stratégia irányába kiterjedtebb területi fejlődést eredményezhet. Az elmúlt évtizedben jó néhány helyi közösség felismerte településének, térségének különleges és értékes adottságait, termelési hagyományait, a helyi munkaerő sajátos képzettségét, és azt is tudatosították, hogy a régió politikai céljait és kulturális adottságait aktivizálva komparatív előnyhöz juthatnak 
más régiókkal szemben. Ezért kiemelten fontossá vált azoknak a tényezőknek a felkutatása, amelyek egy-egy terület önállóbb gazdasági és társadalmi fejlődéséhez, fejlesztéséhez járulnak hozzá. Az agrár- és élelmiszergazdaság területén fellelhető hungarikumok - például a földrajzi árujelzős EU-oltalom alatt álló gönci és kecskeméti kajszibarack vagy békési vörös szilva és a belőlük készült pálinkák - megjelenése elsősorban a vidéki térségekhez köthető, így az endogén elméletek, valamint a versenyképességi megközelítések alapján is a hungarikumok a belső erőforrásokra építő vidékfejlesztési tevékenységek és vidékstratégiák részei lehetnek. Az EU és Magyarország vidékstratégiájában megfogalmazott célokat, a diverzifikált vidéki gazdaság megteremtését, fenntartását részben a hungarikumok verseny- és piacképesebb előállításával, minőségi élelmiszertermeléssel, a hagyományos ökoszisztémák fenntartásával, a táji, természeti és kulturális örökségünk megőrzésével, a vidéki foglalkoztatás bővítésével, illetve az integrált vidéki turizmussal lehet elérni. Az a mód, ahogy a helyi és regionális közösségek századokon át foglalkoztak a környezettel és megművelték a földet, a tájak és a területfelhasználás páratlan sokféleségét eredményezte. E tájak segítenek a különböző régiók identitását kialakítani, és sokszínűségük az európai kulturális örökség fontos eleme. Nemcsak biológiai sokféleséget, történelmi és esztétikai értéket képviselnek, hanem gazdaságilag is fontosak. Egy határozott arculatú táj arra is felhasználható, hogy a térség olyan minőségi tulajdonságait emelje ki, amelyek új iparágakat vonzanak, élénkítik az idegenforgalmat. Kutatásunk is azt mutatja, hogy egy speciális termékre alapozott fejlesztés diverzifikált gazdaságfejlesztést ösztönözhet, így számos kitörési pont lehetőségét jelentheti. A hungarikumok közül kutatásunk négy kiemelt tájkörzethez szorosan kapcsolódó egyedi termék hatását vizsgálja.

\section{Célkitűzések, hipotézisek és az alkalmazott módszerek}

A bevezetőben érintett elméletekhez kapcsolódva saját kutatásunk célja az volt, hogy megvizsgáljuk az eredetvédett pálinkák példáján, vajon a hungarikum védjeggyel ellátott termékek mennyiben tudnak hozzájárulni egy adott térség fejlödéséhez, illetve jelentenek-e olyan sajátos erőforrást, melyekre lokális, endogén fejlesztéseket lehet építeni. A vizsgálat tárgyát képező hungarikumokat, a pálinkát, a hazai vidéki térségek állapotát és sajátosságait figyelembe véve, valamint a helyi és endogén fejlesztésekkel kapcsolatos szakirodalomból és kutatási eredményekből kiindulva a vizsgálat lefolytatása előtt néhány hipotézist fogalmaztunk meg:

- A hungarikumok egy-egy területegység egyedi, nemzetközi szinten is megjelenő endogén erőforrásai, és ennek révén gazdaságfejlesztési irányok alapjául szolgálhatnak.

- A hungarikumok esetén meghatározhatók közvetlen és közvetett térségi hatások. Így a hungarikumok - mint speciális endogén erőforrások - hozzá- 
járulnak az érintett térségek helyi fejlesztésének és gazdasági lehetőségeinek bővítéséhez, munkahelyek létesítéséhez és megtartásához, az ott élők életminőségének javításához, ezzel is segítve a vidéki gazdaság fejlödését.

- A pálinkák mint hungarikumok és a pálinkaágazat megjelenése a helyi fejlesztési tervekben, koncepciókban nem megfelelő, nem élvez prioritást, kellő hangsúlyt.

Kutatásunk területileg a békési szilva-, a gönci barack-, a kecskeméti barack-, és a pannonhalmi törkölypálinka földrajzi árujelző oltalom, illetve eredetvédettség által lehatárolt termőterületére, pontosabban a négy pálinka termékleírásában felsorolt településekre korlátozódott (FVM 2000, 2001, 2009, 2014) (1. ábra). Vizsgálatainkhoz szekunder és primer módszereket is használtunk. Statisztikai adatokat gyüjtöttünk az eredetvédelemben érintett térségekről, településekről. Felhasználtuk többek között a KSH adatbázisait (STADAT, Általános Mezőgazdasági Összeírás - ÁMÖ, Településstatisztikai Adatbázisrendszer - T-STAR), valamint a Magyar Turizmus Zrt. adatait. Ezen adatok elemzésével mutatjuk be a vizsgált térségek általános állapotát, a mezőgazdaság - és ezen belül is a gyümölcságazat - szerepét, a termelés feltételrendszerét.

Dokumentumelemzéssel vizsgáltuk az érintett LEADER akciócsoportok vidékfejlesztési helyzetelemzéseit és helyi vidékfejlesztési stratégiáit, valamint az adott térségekre vonatkozó egyéb fejlesztési koncepciókat (integrált városfejlesztési stratégiákat, területfejlesztési terveket, gazdaságfejlesztési stratégiákat, kistérségi társulások stratégiai programjait stb.). E tervek segítségével azt vizsgáltuk, hogy megjelennek-e, és ha igen, akkor megfelelő hangsúllyal szerepelnek-e a hungarikumok, a rájuk alapozó vagy rájuk vonatkozó intézkedések, fejlesztési elképzelések e dokumentumokban.

Primer adatgyüjtést is végeztünk, amelynek során 63 mélyinterjút készítettünk a négy eredetvédett pálinka előállításában és gondozásában részt vevő személyekkel (gyümölcstermesztőkkel, pálinkafőzdék munkatársaival, kereske-

1. ábra: A vizsgált eredetvédett pálinkák eloállítási területe Pálinka fruit brandys under protection of designation of origin

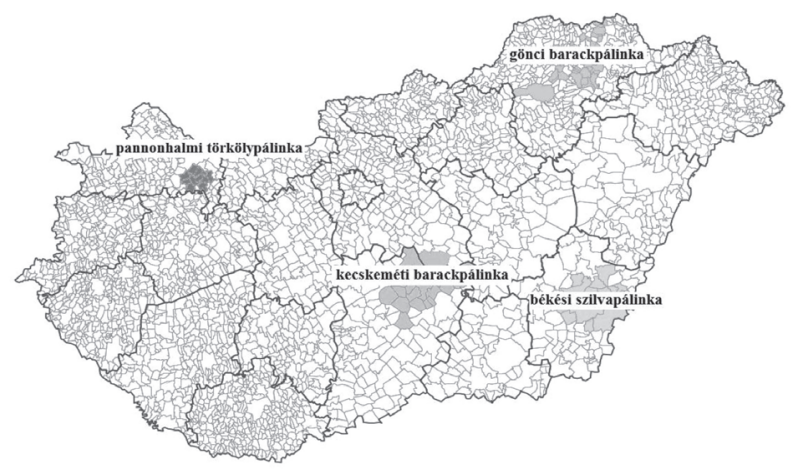

Forrás: FVM (2000, 2001, 2009, é.n.) a lapján saját szerkesztés. 
2. ábra: A kutatás során megkeresett térségi szereplők megoszlása (\%)

The distribution of interviewees across sectors (\%)

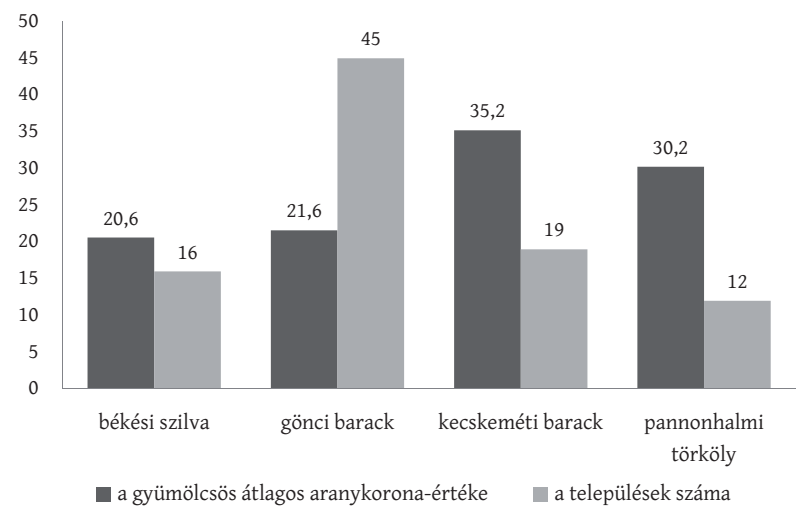

Forrás: saját szerkesztés.

dőkkel), a helyi vidékfejlesztés fontosabb szereplőivel (falugazdászokkal, polgármesterekkel, képviselőkkel, LEADER projektmenedzserekkel, vidék- és területfejlesztési célú civil szervezetek vezetőivel) és a térségekben megtalálható turisztikai szolgáltatókkal (vendéglátóhelyek tulajdonosaival, turisztikai célú civil szervezetekkel, a turisztikai desztinációmenedzsmentek vezetőivel) (2. ábra). Az interjúkra 2014 februárjában és márciusában került sor.

\section{Kutatási eredmények}

A gazdaságfejlesztési irányok elemzéséhez a termelési potenciál kapcsolatrendszerét vizsgáltuk. E vizsgálatokból - terjedelmi korlátok miatt - csak néhány, általunk fontosnak tartott, térbeli összefüggéseket is hordozó eredményt mutatunk be.

A hungarikumok tájkörzeti lehatárolásában meghatározónak tekintjük az ültetvények településenkénti koncentrálódását. A vizsgálati eredményeink alapján termőtájanként 20-30 hektáros átlagos nagyságú termőterületek már lehetőséget biztosíthatnak egyedi termékek termelési rendszerének fenntartásához. Ez számos területfejlesztési irány megfogalmazása esetén jó kiindulási alapot adhat.

Fontosnak tartottuk megvizsgálni azt is, hogy a hungarikumokat termelő termőtáj természeti, földértékelési szempontból mennyire meghatározó (3. ábra).

Kérdésként merülhet fel, hogy egy tájkörzet endogén természeti erőforrásainak minősége milyen mértékben határozza meg a helyi speciális termelés kialakulását, illetve versenyezik-e a hagyományos termelési ágazatokkal. Az adatokból megállapítható, hogy a termelés jó minőségü termőterületeken valósul meg, hiszen minden termőtáj esetében az országos átlag (20 AK) vagy afeletti aranykorona-értéken folyik a hungarikumot adó gyümölcsök termesztése, 
3. ábra: A hungarikumot adó gyümölcsösök átlagos aranykorona-értéke és a települések száma a termőterületen

Land value (golden crown) of Hungaricum orchards and the number of municipalities in the area of origin

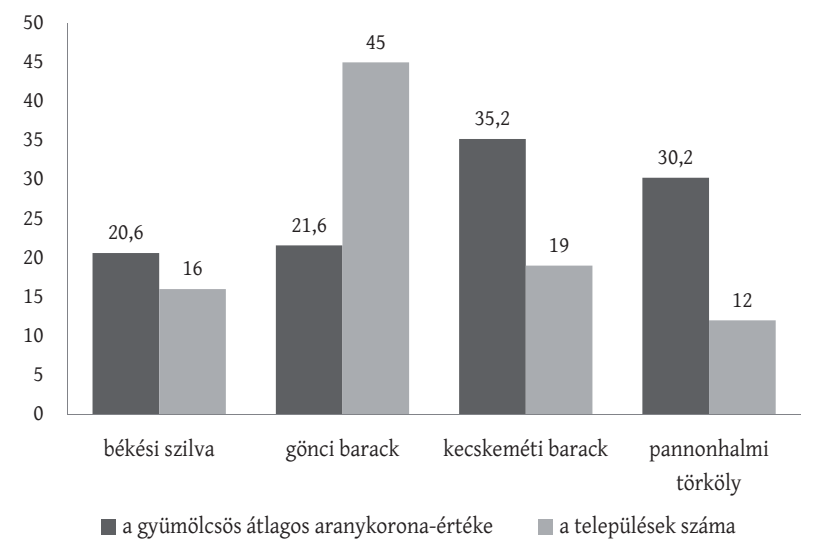

Forrás: KSH ÁMÖ (2010) adatok alapján saját szerkesztés.

közülük is kiemelkedik a kecskeméti tájkörzet (3. ábra). Ez a gazdasági döntések megalapozottságát mutatja, bár az ültetvények tervezése legalább 15-20 évre szól. Egyedi helyi termékek előállításához nélkülözhetetlen a minőségi alapanyag előállítása és a hosszú távú tervezés. A vizsgált tájkörzetekben a gazdálkodói réteg szorosan kapcsolódik az unikális javakat termelő ágazathoz. Az érintett térségekben az összes vállalkozás átlagosan 25\%-a foglalkozik a vizsgált hungarikumok alapanyagát is előállító gyümölcstermesztéssel (4. ábra).

Az interjúkból kiderült, hogy vizsgált termőtájainkon a hálózati jelleg magával hozza az innovációs közeg kialakulását. Innovációs közegen olyan csopor-

4. ábra: Gyümölcstermeléssel foglalkozó gazdaságok aránya az összes vállakozásból a vizsgált térségekben (\%)

Share of companies in fruit production in the four examined areas (\%)

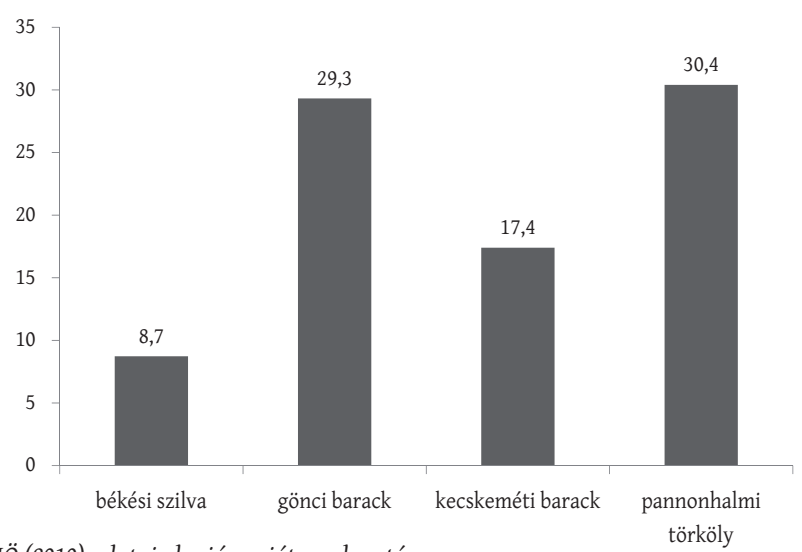

Forrás: KSH ÁMÖ (2010) adatai alapján saját szerkesztés. 
tot értünk, amelynek tagjai között gazdasági, termelési kapcsolatok alakultak ki az adott térségben és termelési kultúrában. A megkérdezettek véleménye szerint figyelembe véve az elmúlt évtizedek hagyományos termelési rendszereit, kollektív tanulással - helyben meghatározott formában - a hungarikumok hozzájárulnak az innovációs folyamatok terjesztéséhez, s egyben csökkentik a piaci kapcsolatok bizonytalanságait, növelik a termelők és a helyi gazdaság versenyképességét. A kialakult gazdasági miliőt a helyi kultúrában, a társadalmi kapcsolatokban és az intézményrendszerben meglévő sajátosságok is alakítják.

A vizsgálataink megerősítették, hogy az adott földrajzi hely szerepe meghatározó. Ezen túl a területi koncentráció lehetőséget nyújt az információk cseréjéhez, az ismeretek és kapcsolatok átadásához. A hagyományok, a kultúrában megőrzendő értékek és az együttműködések új terei nyitottabb társadalmi, politikai, közösségi hátteret teremtenek, amely segít az újdonságok befogadásában.

Arra a kérdésre, hogy adott pálinka jogosan került-e be a hungarikumok közé, az összes válaszadó - függetlenül attól, hogy pálinkafőzde, turisztikai vagy egyéb térségi szervezet képviselője volt-e - egyöntetűen igennel felelt. A megkérdezett fózdék túlnyomórészt hagyományos, kisüsti eljárást alkalmazó (bér)fözdék, az általános kapacitás az 500 literes főzőüst volt. Ezek a fözdék jellemzően az utóbbi 20-25 évben, elsősorban önerőből alakultak, de találtunk rendszerváltás előtti közösségi főzdéket is, esetenként a szocialista időszak előttieket is. A megkeresett fözdék közül kevesebben foglalkoznak kereskedelmi célú termék-előállítással (számos esetben a modernebb, tornyos technológiát használva), ők azok, akik közvetlenül hungarikum eredetmegjelöléssel, ennek megfelelő ellenőrzéssel és tanúsítással rendelkező „hungarikum pálinkát” állítanak, állíthatnak elő. Ugyanakkor meg kell említeni, hogy a megkérdezett fózdék közül több is tervezi a kereskedelmi célú tevékenységet, és ezen belül az eredetvédett termék előállítását. A válaszadók véleménye alapján a térségi bérfőzdék a helyi minőségi alapanyag helyi és hagyományos feldolgozásával pontosan olyan hungarikum jellegü terméket állítanak elő, amelyet az előírások - a NÉBIH-ellenőrzésen keresztül - csak a kereskedelmi főzdék számára engedélyeznek. A hungarikum kereskedelmi értékesítéséből tehát csak a jogosultsággal rendelkező cégek részesednek közvetlenül, a jellemzően kisebb volumenü bérfőzdék nem. A hivatalos kereskedelmi értékesítés jellemzően a térségen kívüli piacokat célozza meg (kiemelhető Budapest mint fó értékesítési piac), de a pálinkák esetenként a helyi értékesítési pontokon, illetve kereskedelmi láncok révén országszerte is megvásárolhatók. Az értékesítés fő színtere a hazai piac, a külföldi értékesítés elenyésző. A válaszok alapján a fogyasztásban 80-90\%-ban a belföldi részesedés a jellemző.

A helyi foglalkoztatás szempontjából a kisebb fözdék, illetve a bérfőzdék jellemzően családi vagy kisvállalkozásként üzemelve 2-5 fönek adnak - gyakran időszaki - munkát, a nagyobb kereskedelmi fózdék általában 8-10 embernek biztosítanak állandó munkahelyet. Természetesen olyan nagyobb cégek is előfordulnak (például a Miskolci Likőrgyár Zrt. vagy Kecskeméten a Zwack), ahol nagy- 
ságrendekkel többen dolgoznak, ám ezek a vállalatok nem kizárólag eredetvédett termék előállításával foglalkoznak. A pályázati tevékenységet vizsgálva megállapítható, hogy többségében a kereskedelmi fözdék vettek igénybe támogatásokat, és csak egy-két esetben - kisebb értékben - a bérfózdék. A támogatásokat túlnyomórészt gépbeszerzésre, technológiai felújításra fordították.

Az alapanyag, amelyből a főzdék a pálinkát előállítják, 71\%-ban az adott főzde közvetlen települési környezetéből, összességében pedig közel 86\%-ban az eredetvédettséggel rendelkező térségből származik (ez a kereskedelmi célú főzdék és a földrajzi eredetvédettség alá eső gyümölcsök esetében 100\%-ban így van), az eredetvédett térségen kívülről származó gyümölcs aránya 14\%. Így a pálinkát előállítók és térségük termelői között gazdasági kapcsolatok alakultak ki - a hungarikumoktól függetlenül is. A kereskedelmi célú fózdék rendelkeznek állandó beszállítókkal vagy saját alapanyag-termeléssel. A bérfőzdékben nem jellemző a saját alapanyag feldolgozása, viszont a főzetők esetében is állandó körről beszélhetünk.

Arra a kérdésre, hogy a vizsgált pálinkák hungarikummá válása volt vagy van-e hatással a fözde tevékenységére, 100\%-ban igen volt a válasz, eltérést csak ennek a hatásnak a nagyságrendjében vagy közvetlenségében tapasztaltunk. A főzdék szempontjából a hungarikummá nyilvánítás egyfajta reklámként, figyelemfelkeltőként volt érzékelheto", ami kismértékben a fözetett mennyiségben (illetve az adott gyümölcs arányában az összes feldolgozott alapanyagban), jelentősebben a pálinka növekvő keresletében realizálódik. Másrészről a bérfőzdékben elóállított pálinka, pontosabban az annak alapjául szolgáló beszállított cefre minőségi javulásában figyelhető meg a hatás. A vizsgált hungarikumok mint kiemelt hazai és helyi termékek - a térségi termelők és főzetők patriotizmusának, büszkeségének táptalaján - a nem kereskedelmi forgalomba kerülő pálinkák minőségi javulását is erősítették, és ezek a minőségileg egyre javuló, egyre népszerübb helyi termékek közvetve a helyi lakosok, termelők gazdasági lehetőségeit is szélesítik, erősítik. Ugyanakkor a hungarikummá nyilvánítás óta nem észleltek közvetlen pozitív hatást a termelés, a foglalkoztatás növekedésére vagy az értékesítési ár változására.

Megvizsgáltuk, hogy van-e együttmüködés az előállítók és a térség bármely turisztikai szolgáltatója, turisztikai szervezete, helyi önkormányzatai vagy az illetékes helyi LEADER-akciócsoportok között. Az eredmények alapján - bár az általánosan jó kapcsolatokat meg lehet említeni - konkrét együttműködés jellemzően nem alakult ki. Ennek ellenére véleményünk szerint a felsorolt szereplők és a főzdék közötti informális kapcsolatok kiindulópontjai lehetnek a későbbi együttmüködéseknek. Kimutatható eredmény viszont a kereskedelmi célú főzdék termékeinek mások általi forgalmazása, értékesítése, a vendéglátóhelyekkel való kapcsolata, illetve a pálinkák térségi rendezvényeken való megjelenése. Az összes válaszadó 85\%-a jelölte meg a fenti kapcsolatok eredményességét.

A térségekben működő turisztikai szervezetek és együttműködések az érintett települések önkormányzatait, szállásadóit, turisztikai szolgáltatóit fog- 
ják össze. Ezek a szervezetek a pálinkát mint hungarikumot nem használják reklámként tevékenységük során. A hungarikum közvetetten, a turizmus kínálati oldalán jelenik meg, elsősorban gasztronómiai elemként, illetve a hozzá kapcsolódó rendezvényeken, eseményeken keresztül. A hungarikum- vagy pálinkaturizmust erősítő hatást az összes megkérdezett szereplő egyértelműen megerősítette, bár inkább az áttételes hatásokat és a kínálatbővítést emelték ki. Csupán minden negyedik válaszadó gondolta úgy, hogy a hungarikum a térség fó vagy fontos turisztikai eleme.

A turisztikai tevékenységet végző válaszadók szerint sem jellemző a szoros együttműködés a turizmus aktorai és a pálinkát elóállítók között az általánosan meglévő jó viszony ellenére. Egy-egy bérfőzde körüli településeiben elvétve találkozhatunk csak tudatos kooperációval (ilyen például a kóstoltatás, a főzdelátogatás, a közös marketingtevékenység, a fözde termékeinek értékesítése). A térségi rendezvényeken, turisztikai eseményeken a hungarikumpálinka megjelenése és szerepe erősebb. A gyenge kooperáció legfőbb oka a bizalmatlanság.

\section{A hungarikumpálinkák megjelenése a fejlesztési dokumentumokban}

A fejlesztési tervek elemzésekor csak a 2007-2013-as programozási periódus dokumentumai álltak rendelkezésünkre. A helyi fejlesztési stratégiák vizsgálatakor az érintett térségek közül csak a gönci területen tapasztaltuk, hogy foglalkoztak a hungarikumpálinkával mint helyi termékkel és endogén erőforrással. A helyi vidékfejlesztési stratégiákban ez tetten érhető volt, az Abaúj LEADER Egyesület zászlóshajó-funkcióként nevesítette a pálinkát. A legtöbb stratégia viszont nem kezelte kiemelten a vizsgált termék helyi fejlesztésre gyakorolt hatását, bár a vizsgált térségekben a 2007-2013-as programozási időszakban számos fejlesztés valósult meg, amely közvetlenül vagy közvetve a pálinka termékláncához, illetve annak turisztikai kihasználhatóságához illeszkedik. A megvalósult fejlesztések szélesebb értelemben véve hozzájárultak a térségek gazdasági, társadalmi és természeti környezetének javításához.

A kutatás alapján vállalkozásfejlesztéssel, a termékek elsődleges feldolgozását elősegítő beruházások révén jelentős foglalkoztatásnövekedés és jövedelemtöbblet érhető el (előbbi főleg a képzetlen munkaerő bevonásával). Az érintett termőtájak vidékfejlesztési stratégiáiból kiindulva fontos a mezőgazdaság támogatása, a jövedelemszerzési és vállalkozási lehetőségek elősegítése, nemcsak a gazdálkodók, hanem a munkaképes vidéki lakosság számára is. A támogatott intézkedések elősegítik a magas hozzáadott értéket eloállító gazdálkodást, a helyi piacra jutást, a közösségi önellátást, valamint támogatják a helyi élelmiszertermelést és -forgalmazást. Ezen túl hozzájárulnak a helyben foglalkoztatáshoz, a helyi kisvállalkozások fejlődéséhez, a családi, kisközösségi gazdálkodási formák elterjesztéséhez, a falusi életmód, a hagyományokon alapuló 
megélhetési formák térnyeréséhez, valamint az egyedi, jó minőségü termékek előállításához. A hungarikumokra alapozó fejlesztések így erősítik a térségben a településeken belüli termékfeldolgozási folyamat kialakítását, a termelők, gyártók egymás közti kereskedelmi kapcsolatainak javítását. Hozzájárulnak a vidéken élők megélhetésének javításához, a hátrányos helyzetű társadalmi csoportok felzárkózásához. Közvetve lehetőséget biztosítanak a vidéken élők képzéséhez, hozzáférést az információhoz és a tudáshoz, segítik a gazdálkodást támogató helyi szellemi kapacitások, szolgáltatások kiépítését. Elősegítik az élelmiszertermelő és a fogyasztó egymásra utaltságának felismerését, valamint a gazdaközösségek és a helyi társadalom kapcsolatának javítását, ezzel jelentős szerepet játszanak a helyi közösségek építésében, fejlesztésében. Mindezek ellenére az érintett akciócsoportokban csak néhány, a pálinka eloállításhoz köthető pályázatot támogattak, amelyek a helyi termék előállításához kötődő gépbeszerzést, technológiafejlesztést és felújítást szolgáltak, jellemzően a kereskedelmi célú fözdékben. A kisebb kapacitású, illetve bérfőzdék pályázati aktivitása nem volt kimutatható az akciócsoportok tevékenységében. A támogatásokkal kapcsolatban a helyi fejlesztéssel foglalkozók a pályázati lehetőségek és források bővítését, kis értékű támogatások lehetőségét és a kisebb főzdék számára való elérhetőségét is fontosnak tartják. Ennek révén megvalósítható lenne a bérfőzdék számára is a kis léptékű technológiai fejlesztés, a minőségi pálinka előállításának irányába történő elmozdulás.

Bár a munkaszervezetek vezetői szerint nem jellemző az együttműködésre törekvés, kedvező jeleket lehet tapasztalni jellemzően a kereskedelmi fözdék és néhány vendéglátóhely, turisztikai szolgáltató, esetenként egy-egy önkormányzat között. Szélesebb területi hatásról lehet beszélni, mivel a főzdék bevételén, az ott biztosított munkahelyeken túlmenően az eloállított termékből származó haszon a turizmuson, a helyi gazdaságon keresztül „leszivárog” a környező települések termelői, lakói, vállalkozói számára. A jó minőségű helyi hungarikum egyértelműen hozzájárul az adott térség reklámjához, a térség többi termékének népszerüsítéséhez. Kiemelendő az a tény, hogy a hungarikumok erősítik a helyi identitástudatot, a helyi közösség értékeinek ápolását és a helyi közösség fejlödését. Érdekességként megemlíthető, hogy a vizsgált termékek hozzájárulását az országimázshoz (nem konkrétan, mint „gönci barack”, „pannonhalmi törköly” stb., hanem mint ,jó pálinka”) nevesítették a megkérdezettek. Vizsgálatunk szerint a hungarikum mint védjegy nem jelent a külföldi fogyasztóknak, turistáknak jelentős vonzerőt (itt ismét elkülöníthetjük a gönci barackot, mivel a szomszédos Szlovákiában viszonylag ismertebb, mint a többi pálinka). A vizsgált termőtájakra érkező vendégek, külföldi látogatók magáról a hungarikumról - mint egyfajta védjegyről - nemigen hallottak. Nem keresik tehát, illetve aki keresi, az sem azért keresi, mert a Hungarikumok Gyüjteményében szerepel, hanem csak azért, mert pálinka, és helyben megtalálható. Így a vizsgált pálinkák mint hungarikumok tágabb értelemben vett hosszabb távú területi hatását ugyan elismerjük, de eredményeink alapján ez a hatás még nem túl jelentős az érintett térsé- 
5. ábra: A vizsgált pálinkák térségre kifejtett hatásának megítélése a

válaszadók véleménye alapján (\%)

The local effect of Pálinka according to the interviewees (\%)

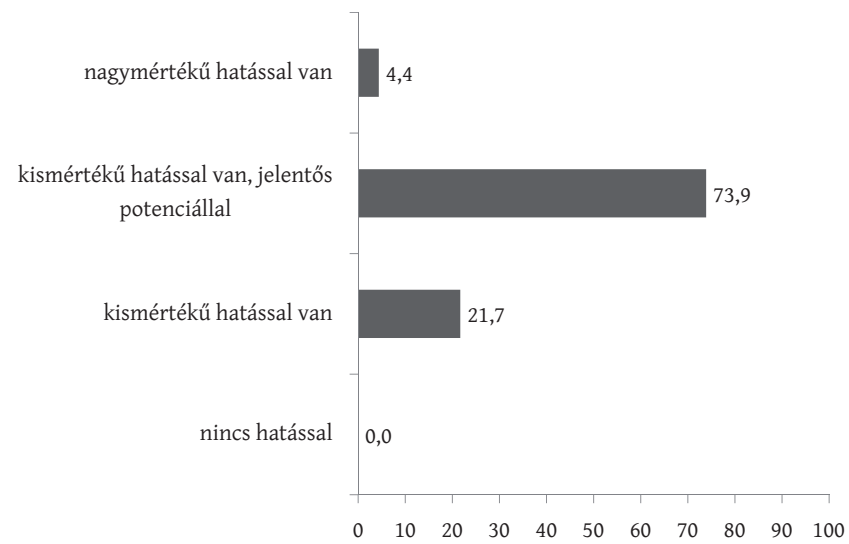

Forrás: saját szerkesztés.

gek és lakóik számára. Ugyanakkor olyan potenciált hordoznak magukban, amely a megkérdezettek közel háromnegyede szerint az érintett területek gazdasági és társadalmi fejlődéséhez érdemben hozzájárulhat (5. ábra).

\section{Összegzés}

Primer kutatásunk alapján elfogadjuk azt a feltevést, hogy a vizsgált pálinkák érdemesek a hungarikum védjegyre, hiszen sajátos erőforrásokat jelentenek, és bár nemzetközi viszonylatban nem nevesítve ismertek, minőségük révén hozzájárulnak az országimázshoz. Megállapítottuk, hogy a vizsgált helyi termékeket tekintve meghatározhatók a közvetlenül és közvetetten is jelentkező hasznok (elsősorban a terméklánc szereplői számára), és érezhető a hatásuk a térség bővülő foglalkoztatásában. Közvetett előnyként lehet értelmezni azt a hasznot, amelyet a főzdék az adókon keresztül a helyi önkormányzatoknak jelentenek. A helyi termék előállítása, a helyi igények helyi termékekkel való kielégítése mindenképpen előnyös az adott lokalitás számára. Ezen túlmenően a hungarikumokat olyan minőségi reklámhordozóknak tartjuk, amelyek nemcsak a település, hanem egy-egy térség gazdasági, társadalmi folyamataira, fejlesztési lehetőségeire is kihatással vannak, és amelyek a helyi fejlődés - ha nem is egyetlen és kizárólagos - mozgatórugói lehetnek. Vizsgálataink alapján a legfontosabb térségi hatások:

- a helyi adóbevételek növekedése,

- hozzájárulás a munkahelyteremtéshez és -megtartásához,

- a helyi alapanyag beszállítás biztosabb értékesítést teremt,

- alternatív jövedelmi és diverzifikációs lehetőség a helyi gazdálkodóknak, 
- a helyi vendéglátás és turizmus fejlődése,

- a hungarikum mint védjegy hozzájárul a térség ismertségéhez,

- a többi helyi termékre gyakorolt hatás.

Összességében a hungarikumpálinkák szerepét mint endogén erőforrás igazoltnak tartjuk, közvetlen és közvetett térségi hatásait megerősítjük, ugyanakkor mind a nemzetközi ismertségét, mind a konkrét térségi hatásait jelen állapotában még csekélynek ítéljük. Ehhez hozzájárul az is, hogy a pálinkák és a pálinkaágazat megjelenése a vizsgált helyi fejlesztési tervekben nem élvez kellő hangsúlyt.

Javaslatként megfogalmazható, hogy a helyi speciális termékek helyét és szerepét a helyi fejlesztési tervekben, a hosszú távú stratégiákban e hungarikumtermékekben rejlő potenciálnak megfelelően erősíteni szükséges, tekintettel arra, hogy a helyi termékek szélesebb területi hatást a munkahelyteremtésen, a feldolgozottsági fok növelésén, a kapcsolódó ágazatok (pl. turizmus) fejlődésén keresztül fejthetnek ki.

\section{Köszönetnyilvánítás}

A kutatást a Pálinka mint hungarikum területi jelentősége Magyarországon című (HUNG-624/2013. azonosítószámú) projekt keretében végeztük, amely a Vidékfejlesztési Minisztérium és a Hungarikum Bizottság támogatásával valósult meg 2014 tavaszán. A kutatásban a szerzőkön kívül részt vett Farkas Tibor egyetemi docens, Urbánné Malomsoki Mónika tanszéki mérnök, valamint Áldorfai György és Czabadai Lilla PhD-hallgatók, akiknek köszönetünket fejezzük ki a kutatásban való közreműködésükért.

\section{Irodalom}

Belletti, G., Marescotti, A., Scaramuzzi, S. (2003): Paths of rural development based on typical products: a comparison between alternative strategies. In: Cristovao, A., Omodei, Z. L. (eds.): Farming and rural systems research and extension - Local identities and globalisation. Fifth IFSA European Symposium Florence, ARSIA, Firenze, 384-395.

Cernea, M. (1992): The building blocks of participation. World Bank, Washington http://doi.org/bwkj99

Endrighi, E. (1999): La valorizzazione delle produzioni tipiche locali. Dal concetto di valore alle indicazioni operative. Rivista di Economia Agraria, 1., 3-26.

Farkas T. (2002): Vidékfejlesztés a fejlődéselméletek és a fejlesztési koncepciók tükrében. Tér és Társadalom, 1., 41-57.

FVM (2000): Kecskeméti barackpálinka termékleírása. http://elelmiszerlanc.kormany.hu/ download/6/3e/40000/20_kecskemeti_barackpalinka_2.pdf (Letöltés: 2014. február 2.)

FVM (2001): Békési szilvapálinka termékleírása. http://elelmiszerlanc.kormany.hu/download/4/3e/40000/18 _bekesi_szilvapalinka_2.pdf (Letöltés: 2014. február 2.)

FVM (2009): Pannonhalmi törkölypálinka termékleírása. http://elelmiszerlanc.kormany.hu/ download/3/3e/40000/17_\%20pannonhalmi_torkolypalinka.pdf (Letöltés: 2014. február 2.)

FVM (é.n.): Gönci barackpálinka termékleírása. http://elelmiszerlanc.kormany.hu/download/5/3e/40000/19 _gonci_barackpalinka_3.pdf (Letöltés: 2014. február 2.) 
Káposzta J. (2007): Regionális gazdaságtan. Szent István Egyetem Kiadó, Gödöllő

Kis K., Szekeresné Köteles R. (2010): A helyi akciócsoportok szerepe a versenyképes és fenntartható vidékfejlesztés megvalósításában. Tér és Társadalom, 3., 119-135

Kulcsár L. (szerk.) (2006): Vidékfejlesztés. Szent István Egyetem, GTK, Gödöllő

Lowe, P., Murdoch, J., Ward, N. (1995): Networks in rural development: beyond exogenous and endogenous models. In: van der Ploeg, J. D., van Dijk, G. (eds.): Beyond modernisation: The impact of endogenous rural development. Van Gorcum, Assen, 87-105.

Moseley, M. J. (2003): Rural development: Principles and practice. SAGE, London

Murdoch, J. (1995): Sustainable rural development: Towards a research agenda. Geoforum, 3., 225-241. http://doi.org/d6hk74

Pacciani, A., Belletti, G., Marescotti, A., Scaramuzzi, S. (2001): The role of typical products in fostering rural development and the effects of regulation (EEC) 2081/92. http://www.origin-food.org/pdf/ partners/belmarscaparole.pdf (Letöltés: 2014. március 14.)

van der Ploeg, J. D., van Dijk, G. (eds.) (1995): Beyond modernization: The impact of endogenous rural development. Van Gorcum, Assen

Rechnitzer J. (1990): Szempontok az innovációk térbeli terjedésének kutatásához. MTA RKK, Pécs, 48-62.

Terluin, I. J., Post, J. H. (2001): Key messages on employment dynamics in leading and lagging rural regions of the EU. LEI Agricultural Economics Research Institute, Den Haag

Török Á. (2012): Az eredetvédelem jelentösége a magyar pálinka ágazatban. http://napok.georgikon.hu/ cikkadatbazis-2012-2013/cat_view/3-cikkadatbazis/4-2012/9-viii-szekcio-agrar-es-videkgazdasag (Letöltés: 2014. március 7.) 
$\frac{1}{2}$ 